\title{
経皮吸収の原理・その実際・今後の期待
}

\section{Theory, Practical Application and Future Expectation of Percutaneous Absorption}

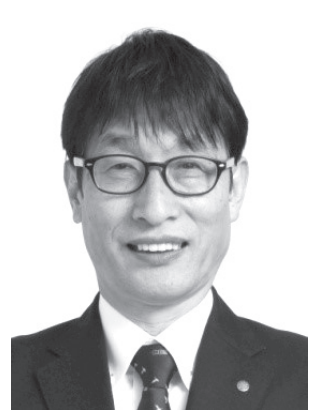

\author{
杉林 堅次 \\ 城西大学薬学部 \\ T 350-0295 \\ 埼玉県坂戸市けやき台 1-1
}

Kenji SUGIBAYASHI

Faculty of Pharmacy and Pharmaceutical Sciences,

Josai University

1-1 Keyakidai, Sakado, Saitama, 350-0295, Japan

論文要旨：簡便な DDS としての外用剤と経皮吸収型製剤（TDDS）を今後さらに開発・発展させていく ためには, 皮䖉の構造について理解し, 薬物の経皮吸収について十分理解することが必要である。ここでは, 経皮吸収経路とその速度論について, さらには特に外用剤の評価で重要となる皮膚中濃度動態について解説 した。また, 実用化に当たって重要である吸収促進剤の利用や外部エネルギーを利用した製剂化に関しても 説明した。今後は, AI P IoT の発展に伴い全く新しいタイプの TDDS が世に出ると期待される。今はまさ に将来のために過去を振り返る時であると思われる。

\begin{abstract}
In order to further develop topical dosage preparation and transdermal drug delivery systems (TDDS) as a convenient DDS, it is necessary to fully understand the skin structure and the percutaneous absorption of drugs. Here, the author explained skin penetration pathway of drugs and kinetics aspect for the percutaneous absorption of drugs as well as skin concentration profiles, which are important especially for evaluation of topical dosage preparation. In addition, the author explained about the use of skin-penetration enhancers and physical means to increase the skin permeation of drugs, which are important in practical application. Great progress of AI (artificial intelligence) and IoT (internet of things) may derive completely new types of TDDS in the near future. That is why it is time to look back on the past for the sake of the future.
\end{abstract}

Key words: percutaneous absorption, skin permeation, skin concentration, topical dosage preparation, transdermal drug delivery system

\section{1 はじめに}

簡便で有効な DDS としての皮膚に適用する医薬品製 剂には, 皮膚局所およびその近傍での薬効を期待した, いわゆる局所作用型製剂（外用剂）と皮膚を通して有効 成分を全身循環系に送達させることを目的とした，いわ ゆる（全身作用型）経皮吸収型製剂（Transdermal Therapeutic Systems, TTSまたは Transdermal Drug Delivery Systems, TDDS, 以下 TDDS と略記)があるが, 両者に剂形的な差異はほとんどない。外用剤では有効成 分が疾患部位に直接作用するので，全身的な副作用の危

連絡者：杉林 堅次

E-mail : sugib@josai.ac.jp
険性は低い。一方, TDDS は薬物が皮膚を通して全身 循環血流に送達されるべく設計されており, 多くの経口 剤などと同様に全身的な薬効が期待できる。TDDS は 投与が簡便で, 初回通過効果を回避でき, 副作用発現の 際には製剤を皮膚から取り除き投与を中断できる利点が あり，モノリシック型のテープ剤と薬物槽をライナーで 覆ったリザバー型製凨が中心である。これらは長時間に わたり安定した薬物の供給が可能で, 代表的な薬物送達 システム（ドラッグデリバリーシステム, DDS）になっ ている。

TDDSではもちろんのこと外用剂であっても有効成 分が, 皮膚の表面にあり経皮吸収の最大のバリアーと なっている角層（stratum corneum）を透過しなければ 
ならない。すなわち，これらでは薬物の経皮吸収が必須 となる。そこで，以下に経皮吸収の原理・その実際・今 後の期待について順を追って説明する。

\section{2 皮膚の構造}

薬物の経皮吸収について考える前に, 皮膚の構造をよ く理解する必要がある。皮膚は表面側から表皮（epidermis）と真皮（dermis）に分けられる。また，皮膚表面 からは毛 (毛髪) が生えており, 皮膚表面には汗腺など も開口している。

皮膚の表面を見ると, 多数の細かい皮溝（sulcus cutis）が刻まれている。また，この皮溝で囲まれた小さ な隆起部分を皮丘（crista cutis）という。毛は皮溝の交 差点から生えているので，毛の開口部は他の実質部より 低く漏斗状に開き，いわゆる毛漏斗（infundibulum）を 形成する。毛を取り囲む組織のことを毛包 (毛囊) (hair follicle）といい，毛は皮膚面に対して斜めに配置してい る。毛包は 2 重構造を取り, 内側は上皮性組織（表皮と 類似)，外側は結合組織（真皮と類似）で構成される。 成長期の毛根の最下部は球状に膨れて毛球となり, 中に 毛乳頭が存在する。

汗腺（sweat gland）は，ほほ全身に分布し皮丘部に 開口しているエクリン汗腺と腋下部や鼠蹊部の皮膚では 皮脂腺孔の上部にあるアポクリン汗腺があり, 汗を作り 体表へ送り出している。さらに, 毛包上部には皮脂腺 (sebaceous gland) 孔があり皮脂（sebum）を産生する。 皮脂腺は手掌や足底を除く全身の皮膚や粘膜に分布して いる。皮膚表面で皮脂は汗などの水分と混合され，乳化 して皮膚表面をコーティングしている。以上説明した, 毛，皮脂腺，汗腺，そして角化性の上皮組織である爪を 一括して皮膚付属器と呼ぶ。いずれも表皮が形を変えた ものである。

表皮は物質の経皮吸収を語るときもっとも重要な組織 である。その厚みは平均 $0.2 \mathrm{~mm}(200$ ミクロン) であり, 構成する細胞の $95 \%$ はケラチノサイト (keratinocyte : 角化細胞）である（その他の細胞にはメラノサイトとラ ンゲルハンス細胞などがある)。ケラチノサイトは表皮 の最下層にある基底層（基底細胞層）（basal cell layer） でほぼ1日1回分裂し, 成熟に従って分化して上層に移 行する。すなわち, 表皮は成熟に従って異なる形態のケ ラチノサイトが層状に配列し, 深部から基底層（基底細 胞層), 有棘層 (有棘細胞層), 顆粒層 (顆粒細胞層) そ して角層（角質細胞層）となる。なお，手掌や足底では 顆粒層と角層の間に透明層が存在する。

基底細胞は立方体または円柱状の細胞で，一層を形成 する。隣接する細胞とはデスモソーム（desmosome） と裂隙接合（gap junction）で結合しており，また，基 底細胞層下部の表皮基底板（厚さ $60-80 \mathrm{~nm}$ ）とはへミ デスモソーム (hemidesmosome) で結合している。有 棘層は 3-10 層からなり, 細胞はお互い棘で繋がってい る。この棘は細胞間橋（intercellular bridge）と呼ばれ, デスモソームに相当する。顆粒層は 2-3 層からなる。顆 粒層では核も含めてさらに扁平な構造となる。顆粒層で は細胞同士は主に密接結合（tight junction）で結合して いる。密着結合ではオクルディン (occuludin) という 膜タンパクにより細胞膜同士が網目状に密着している。

角層は部位によっても異なるが, 脱核し死んだ組織で ある角層細胞（コーニオサイト, corneocyte）10-20 層 からなる。この組織は落ち葉を敷きつめたような構造と なり, 表面から順に垢となって剥がれ落ちる。この現象 を落屑（desquamation）という。ケラチノサイトの内 側には周辺帯 (cornified envelope, marginal band) と 呼ばれる裏うち構造がみられる。周辺帯を構成する夕ン パクは物理的および化学的刺激に対して非常に安定なケ ラチン（keratin）でできている。また，ケラチノサイ トの周りはセラミド, コレステロール, 遊離脂肪酸など からなる細胞間脂質で囲まれる。

真皮は表皮の下部に存在する厚さ 3-5 mm の組織で, 解剖学的には乳頭層, 乳頭下層そして網状層に分けられ る。真皮を構成する線維芽組織には膠原繊維と弾性繊維 があり，細胞成分は繊維芽細胞（fibroblast）と肥満（マ スト）細胞がある。乳頭下層には血管叢があり, ここか ら小動脈が乳頭層に上行し, 乳頭において係蹄 (capillary loop）を構成して小静脈に移行する。小静脈は吻合して, 動脈の走行と同様に 2 種の血管叢を形成し, 最終的に皮 静脈に流れる。経皮吸収された薬物が真皮に到達すると, その多くが血管中に吸収される。皮膚付属器の周囲には 特異的な血管叢が存在し, エクリン汗腺周辺や成長期毛 包周囲は特に血管網が豊富である。

\section{3 薬物の経皮吸収}

\section{3・1 経皮吸収, 皮膚透過, 皮膚浸透という用語の区別}

ここで，「経皮吸収（percutaneous absorption）」，「皮 膚透過 (skin penetration)」, そして「皮膚浸透」の用 語について定義づけをする。「経皮吸収」はしばしば「皮 膚透過 (skin permeation)」と同じ意味で使われている。 しかし，経皮吸収についてより梁く考えるには，両者を 区別する必要がある。また，もう１つ同様な使い方をさ れるものに「皮膚浸透」がある。

薬物の「吸収（absorption）」は全身循環系（主に体 循環血液）中に薬物が入ることをいう。したがって,「経 皮吸収」は皮膚上にあった薬物が皮膚バリアーを経て血 
管中に入ることを意味する。「吸収」は血液が流れてい ない摘出皮膚や培養皮膚ではありえない（今までの培養 皮膚には血管のあるものは開発されていない)。したがっ て，現在のところ，「経皮吸収」という用語はin vivoま たはin situ研究でのみ使われるべきである。なお, Basketter ら ${ }^{1)}$ は「吸収 (resorption)」という用語を用 いたが，ここでは薬学（薬剤学）で用いる absorption を採用し、「経皮吸収 (percutaneous absorption)」とい う用語を使う。

「皮膚透過」は通常, 皮膚の表側から裏側に化学物質 が移動することである。吸収という文字がないので,「皮 膚透過」はin vitro 研究だけでなくin vivo または in situ 研究でも用いることができる。一方，「皮膚浸透」 は化学部質の浸透部位の深さを問わない。複雑なことに 「penetration」には貫通という意味もあるが，通り抜け るなら「piercing」または「pass through」と考える方 がよい。「penetration」は淩みる(染みる)の意味に近い。 したがって,「皮膚浸透 (skin penetration)」は「皮虐 透過 (skin permeation)」と同様, in vitro 研究だけで なくin vivoまたはin situ研究でも用いることができる。

\section{$3 \cdot 2$ 経皮吸収過程}

「経皮吸収」される薬物が皮膚に触れると, 薬物は皮 膚中に分配（partitionまたは distribution）し深部に浸透。 吸収する。ただし、溶けた薬物だけが皮膚に分配する。 なお，分配は速度過程ではなく平衡現象であるので，多 くの場合一瞬のうちに引き起こるとされる。しかし，こ こで注意すべきことが2つある。1つは, 皮膚上の溶媒(媒 質，以下溶媒と記す）自体が皮膚中に「経皮吸収」する 場合があること，また，溶媒が皮膚の性状（皮膚のバリ ア一能や極性）を大きく変化させる場合があることであ る。溶媒自身が経皮吸収して皮虐バリアー能が減少する と，薬物の経皮吸収性が大きく増加することがある。も う 1 つの問題は「吸着」である。化学物質は皮膚に吸着 することがある。われわれの研究室でも茶葉カテキン類 が皮膚中で吸着する現象を確認している ${ }^{2)}$ 。皮膚に吸着 した化学物質は経皮吸収に直接寄与せず，この点で皮䖉

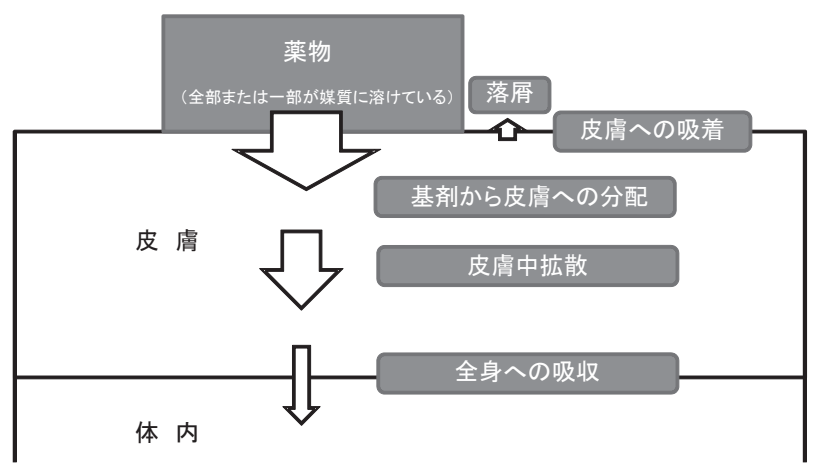

Fig. 1 化学物質の経皮吸収過程

分配とは違う現象であることに注意が必要である。 分配に続いて重要な現象は薬物の皮膚中での「拡散 (diffusion)」である。皮膚に分配した薬物は皮膚マトリッ クス中を拡散する。薬物は濃度の高い方から低い方に移 動するので, 皮膚に分配された化学物質は次第に皮膚深 部に移行する。皮膚を形成する細胞はターンオーバ（新 陳代謝）しているので, 動きの遅い薬物は角層より深部 には至らず，最終的にはフケとなって体から落屑する。 一方, 皮膚深部に移行した薬物の一部は皮膚中の毛細血 管に取り込まれ（吸収され）全身に移行する。これらの 過程を Fig. 1 に示す。

なお，薬物の経皮吸収の最大のバリアーは角層にある ので，角層に分配した薬物が角層を移動し顆粒層に到達 すれば，あとの皮膚透過速度は極めて速い。

\section{$3 \cdot 3$ 経皮吸収経路}

化学物質の経皮吸収経路は大きく分けて, 角質実質経 路と皮膚付属器官経路がある（Table 1)。経皮吸収され る薬物は分子量も小さく適度な脂溶性を有している。こ のような物質はほとんどが角質実質経路を介して経皮吸 収される。また，角層実質経路も角層細胞自体を通る， 経細胞ルート（transcellular route）と角層細胞と角層 細胞の間を埋めている細胞間脂質を通る, 細胞間ルート (paracellular route, intercellular route) がある。角層 実質経路のなかではこの細胞間ルートが中心である。

一方で, 最近は物質の定量感度が上昇し, 以前は確認

Table 1 化学物質の経皮吸収経路

\begin{tabular}{|c|c|c|}
\hline \multicolumn{2}{|c|}{ 経皮吸収経路 } & 備 考 \\
\hline \multirow{2}{*}{ 角層実質経路 } & 経細胞経路 & $\begin{array}{l}\text { ·角層細胞（corneocyte）を通る } \\
\text { ・皮膚およびその近傍への浸透 }\end{array}$ \\
\hline & 細胞間経路 & $\begin{array}{l}\text { ·角層細胞間脂質部分を通る } \\
\text { ·多くの治療薬の経皮吸収経路であると考えられている }\end{array}$ \\
\hline \multirow{3}{*}{ 付属器官経路 } & 毛囊 & $\begin{array}{l}\text { ·高分子やナノマテリアルの侵入が確認されている } \\
\text { ・イオントフォレシス適用時の物質の透過ルートか？ }\end{array}$ \\
\hline & 汗腺 & ・イオントフォレシス適用時の物質の透過ルートか? \\
\hline & 皮脂腺 & \\
\hline
\end{tabular}


されなかった高分子やナノマテリアルの皮膚浸透性につ いても試験されるようになった。詳細は省略するが, こ れらは角層実質経路よりむしろ皮膚付属器官経路が重要 であるとの指摘がある。我々も特に毛囊の寄与が高いこ とを確認している ${ }^{3)}$ 。毛囊透過ルートの研究はにきびの 治療薬や育毛薬にとっては大変重要なテーマになる。

\section{$3 \cdot 4$ 経皮吸収速度決定因子}

皮膚組織への薬物の「分配」が平衡現象であるのに対 し,「拡散」は皮膚中の速度過程である。化学物質の皮 膚中の拡散は，確率的に無作為（ランダム）に決定され る運動，たとえばランダムウォーク (random walk $)^{4)}$ 現象の一種と考えることができる。

Fig. $2 \mathrm{a}$ の薬物の皮膚中濃度一吸収方向プロフィール (concentration-distance profile）に示したように，基剤 から皮膚に分配した薬物が皮膚中を拡散する場合, 基剤 中薬物濃度 $\mathrm{C}_{v}$ が（ほとんど減少せず）ほぼ一定であれ ば（これを無限用量系infinite dose systemという。詳 細は後述）皮膚の基剤界面の薬物濃度 $K C_{v}$ はほほ一定 になる（ここで，Kは基剂から皮膚への分配係数 parti-

(a) Infinite dose system

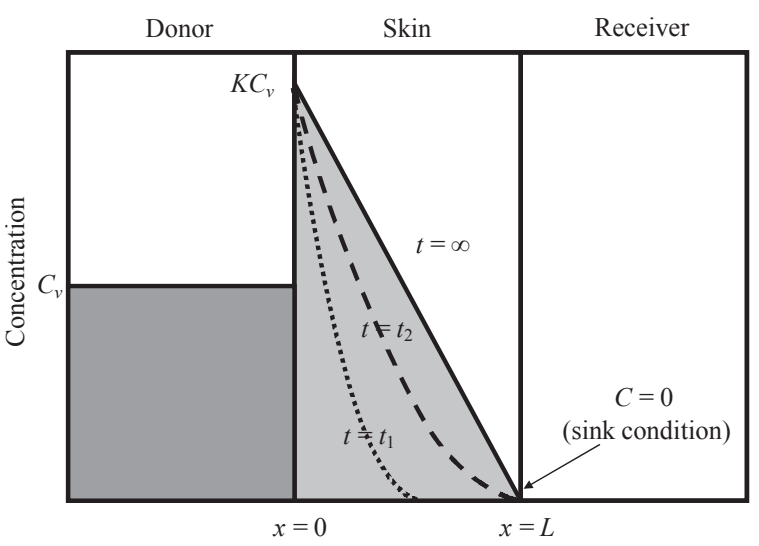

(b) Finite dose system

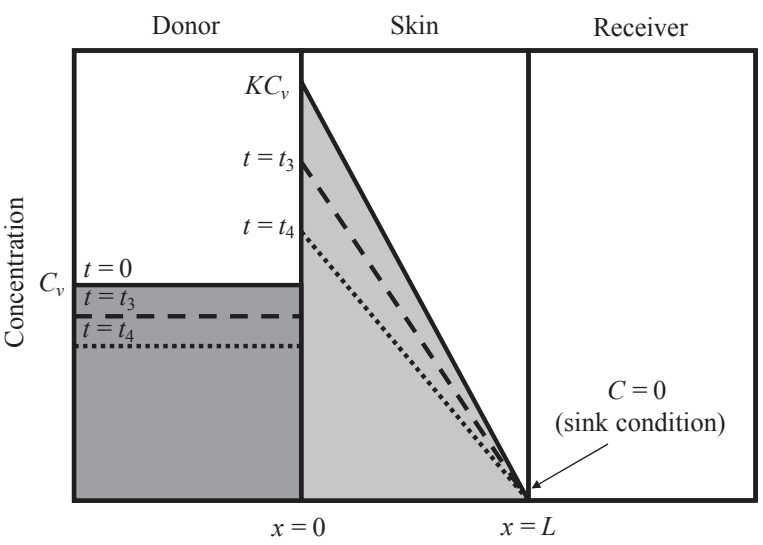

Fig. 2 皮膚中の化学物質の concentration-distance profile tion coefficient)。このとき, 薬物は図の右側に拡散して いくが，右側の皮膚界面でシンク条件（sink condition） が成り立つとすると, 皮膚中の薬物濃度は左の界面から 右の界面まで直線的に落ちていくことになり，皮膚中に はどの深度でも同じ濃度勾配が得られる。

\section{$3 \cdot 5$ 拡散方程式}

薬物の皮膚中拡散は Fickの法則（Fick's law of diffusion）に従う。なお, Fickの法則には第 1 法則と第 2 法 則がある。Fick の第 1 法則（Fick's $1^{\text {st }}$ law of diffusion） は定常状態拡散, すなわち時間によって薬物の皮膚中濃 度が変化しないときに成り立つ。経皮吸収速度（流速, flux）JはFickの第 1 法則により以下の式で示される。

$$
J=-D \frac{d C}{d x}
$$

ここで，Jは単位時間当たりに単位面積を通過する薬物 量と定義され，その単位は $\mathrm{mg} / \mathrm{cm}^{2} / \mathrm{h}$ などである。 $D$ は拡散係数 (diffusion coefficient) といい, 単位は $\mathrm{cm}^{2} / \mathrm{h}$ などである。Cは化学物質の皮膚中濃度で単位は $\mathrm{mg} /$ $\mathrm{cm}^{3}$ などである。そして $x$ は皮膚の深み方向の位置で, 単位は $\mathrm{cm}$ などである。すなわち, Fickの第 1 法則は $J$ が皮膚中の濃度勾配 $d C / d x$ に比例し, 比例定数が $D$ で あることを示している。なお，拡散は $x$ 軸方向だけでな く, $y$ 軸や $z$ 軸でも生じうるが, 化学物質の皮膚中拡散 では $y$ 軸や $z$ 軸方向の拡散は $x$ 軸方向の拡散に比べ無視 しうる。

Fickの第 2 法則（Fick's $2^{\text {nd }}$ law of diffusion）は, 非 定常状態拡散, すなわち, 薬物濃度が時間に関して変化 する時に使われる。Fickの第 2 法則は次式で示される。

$$
\frac{\partial C}{\partial t}=D \frac{\partial^{2} C}{\partial x^{2}}
$$

すなわち, 皮膚中の $C$ は時間 $t$ と皮膚の深み方向の位 置 $x$ で決定される。

\section{$3 \cdot 6$ 経皮吸収速度}

生体膜を通る速度は Fickの法則で解析される受動拡 散だけでなく, 能動輸送, 仲介輸送（促進拡散）さらに は膜動輸送などがあり, 皮膚も生体膜であるのでこれら の輸送過程も考慮にいれる必要がある。しかし, 経皮吸 収の最大のバリアーは死んだ細胞層である角層であるた め, エネルギーを必要とする能動輸送の寄与は無く, ほ とんどの化学物質の経皮吸収または皮膚透過過程は受動 拡散として考えることができる。すなわち, 皮膚透過現 象はFickの法則を用いて解析することができる。もち ろん，この解析では皮膚（または角層）を均一な一枚膜 と仮定していることに注意すべきである。 無限用量系における経皮吸収速度解析法

皮膚に薬物の懸濁液を用いた場合（無限用量系），ド 
ナー側の (溶解型) 薬物濃度は一定に保たれる。また, レシーバ側で常にシンク条件が成立していると仮定でき ると, 式 3 の初期条件 [I.C.], 境界条件 [B.C.] は以下 のように示すことができる。

$$
\begin{array}{rlrl}
\text { [I.C.] } C=0 & 0<x<L \\
\text { [B.C.] } C=K C_{v} & x=0 \\
C=0 & x=L
\end{array}
$$

ここで，Lは皮膚（角層）の厚み $(\mathrm{cm})$ である。式 3 を用いて Fickの第 2 法則を解くと, 次式が求められる ${ }^{5)}$ 。

$$
C=K C_{v}\left[\left(1-\frac{x}{L}\right)-\frac{2}{\pi} \sum_{n=1}^{\infty} \frac{1}{n} \sin \left(\frac{n \pi x}{L}\right) \exp \left(-\frac{D}{L^{2}} n^{2} \pi^{2} t\right)\right] \text { (4) }
$$

式 4 は皮膚中薬物濃度 $C$ が薬物適用（暴露）後の時 間 $t$ と皮膚の深み位置 $x$ の関数として示されることを意 味している。一方, 経皮吸収速度 $J$ は式 1 で示されるの で, 式 4 を $x$ で微分して $d C / d x$ を求め, これを式 1 に 代入すると, 式 3 に示した条件下でのJが求められる。

$$
J=\frac{K C_{v} D}{L}\left[1+2 \sum_{n=1}^{\infty}(-1)^{n} \exp \left(-\frac{D}{L^{2}} n^{2} \pi^{2} t\right)\right]
$$

なお，経皮吸収累積量 $Q\left(\mathrm{mg} / \mathrm{cm}^{2} / \mathrm{h}\right)$ は式 5 を時間 $t$ で積分して次のようになる。

$$
Q=K L C_{v}\left[\frac{D}{L^{2}} t-\frac{1}{6}-\frac{2}{\pi^{2}} \sum_{n=1}^{\infty} \frac{(-1)^{n}}{n^{2}} \exp \left(-\frac{D}{L^{2}} n^{2} \pi^{2} t\right)\right] \text { (6) }
$$

式 6 を時間の関数として Fig. 3 に示す。また, 時間 $t$ に無限大を代入することにより，定常状態時 $(t \rightarrow \infty)$ での $J$ と $Q$ 求めると, 以下の式が得られる。

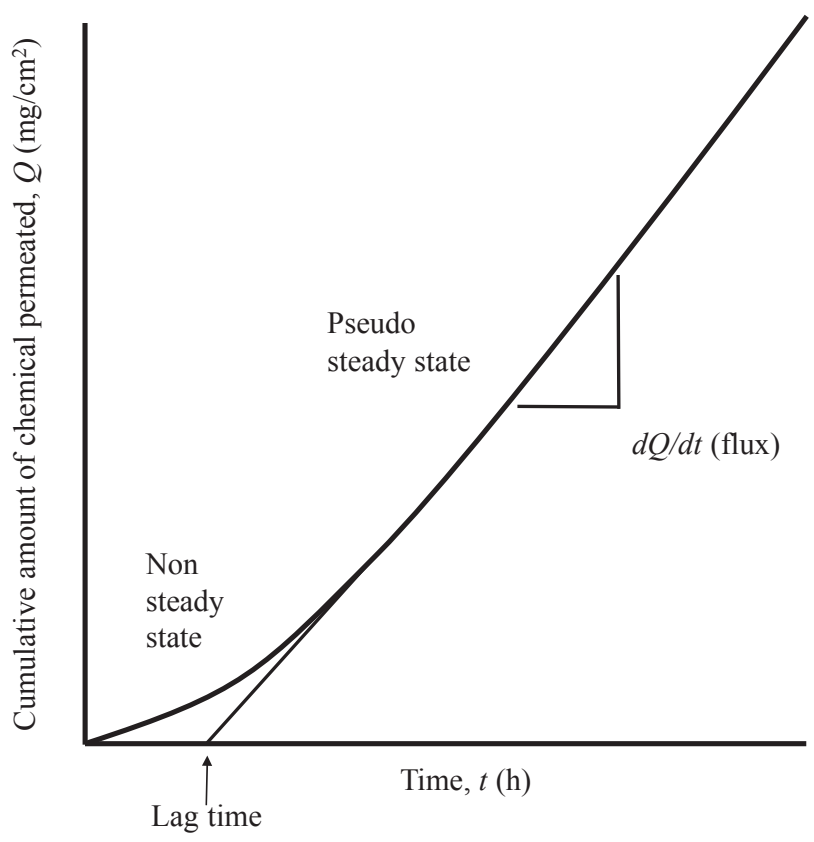

Fig. 3 in vitro 透過実験から得られる典型的な皮膚透過性

$$
\begin{aligned}
& J=\frac{d Q}{d t}=\frac{K C_{v} D}{L}=P C_{v} \\
& Q=\frac{K C_{v} D}{L}\left(t-\frac{L^{2}}{6 D}\right)
\end{aligned}
$$

ここで, $P$ は透過係数 (permeability coefficient) と呼 ばれる。Pは $K D / L$ で求めることができる。経皮吸収 ではこの $P$ の意味づけが大変重要になる。また，式 8 より，定常状態での物質透過速度を外挿して求められる ラグタイム $L T$ は以下のようになる。

$$
L T=\frac{L^{2}}{6 D}
$$

皮膚は複雑な構造をしているが，以上示した式は多く の薬物の皮膚透過性をよく表現するので実用性が極めて 高い。

\section{有限用量系における経皮吸収速度解析法}

無限用量系の式 3 に対して有限用量系 finite dose system での B.C. は次のようになる。

$$
\begin{aligned}
\text { [B.C.] } C & =K C_{v}(t), \quad V \frac{d C_{v}(t)}{d t}=A D \frac{d C}{d x} x \\
C & =0 \\
x & =L
\end{aligned}
$$

ここで， $V$ は製剤の体積 $\left(\mathrm{cm}^{3}\right), C_{v}(t)$ は時間 $t$ におけ る製剤中の化学物質濃度, $A$ は適用面積 $\left(\mathrm{cm}^{2}\right)$ である。

Fig. 2a, b に infinite dose system と finite dose system の concentration-distance profileを比較する。Infinite dose system（Fig. 2a）では，製剤（donor）側の化学物 質濃度がいつも $C_{v}$ に保たれ，定常状態では皮膚中濃度 勾配が一定になるのに対し, finite dose systemでは, $t$ $=0$ から $t=t_{1}, \quad t_{2}$ と時間が経過と共に製剤中濃度が徐々 に下がっていくので, 皮膚中濃度勾配も経時的に減少し ていく(Fig. 2b)。

\section{$3 \cdot 7$ 皮膚バリアーのモデル化}

皮膚の角質実質経路は脂溶性の化学物質が通りやすい ルート (lipophilic pathway) で皮膚付属器官経路は水 溶性化学物質が通りやすいルート（hydrophilic pathway）と考えられる。そこで我々は，この考え方に従っ て皮膚透過モデルとして Parallel permeation pathway model を提唱した ${ }^{6-8)}$ 。もちろん, 一般的に皮膚は脂溶 性膜 (lipophilic membrane) と考えられるので, lipophilic domain が hydrophilic domain より大きく，また， 脂溶性物質の皮膚透過が水溶性物質の皮膚透過より高 い。当然のことながら, lipophilic domain を通る化学物 質の透過速度は $K$ に比例する。ここで， $K$ と $K_{o w}$ には 一般に次のような関係が存在する ${ }^{9)}$ 。 


$$
K=a K_{o w}{ }^{b}
$$

この式中の $a, b$ は係数である。Aqueous pathwayを通 る皮膚透過係数を $c$ と仮定すると, 透過係数 $P$ は $K_{\text {ow }}$ の関数として，以下のように示すことができる。

$$
P=a K_{o w}{ }^{b}+c
$$

Fig. 4 に分子量 300 前後の 16 種の化学物質のヘアレ スラット皮膚およびヒト皮膚を介した透過係数の対数 $(\log P)$ と用いた化学物質の $n$-オクタノール／水分配係 数の対数 $\left(\log K_{o w}\right)$ の関係を示す。ヘアレスラット皮膚 およびヒト皮膚透過係数デー夕を非線形最小二乗法によ り式 12 に当てはめ, それぞれの皮膚の $a, b$ 及び $c$ の值 を算出し，以下の式を得た。

$$
\begin{aligned}
& \text { ヘアレスラット }: P(\mathrm{~cm} / \mathrm{s})=4.78 \times 10^{-7} K_{o w}{ }^{0.589}+8.33 \\
& \times 10^{-8} \\
& \text { ヒ } \quad \text { 卜 }: P(\mathrm{~cm} / \mathrm{s})=1.17 \times 10^{-7} K_{\text {ow }}{ }^{0.751}+2.73 \\
& \times 10^{-8}
\end{aligned}
$$

Fig. 4 中の実線は式 13，14 を示したものである。図 より，化学物質の $K_{o w}$ 值から $P$ を予測できると考えら れた。

\section{$3 \cdot 8$ 皮膚透過に及ぼす分子サイズの影響}

Potts と Guy は経皮吸収速度と分子量の関係式を報告 している ${ }^{10)}$ 。

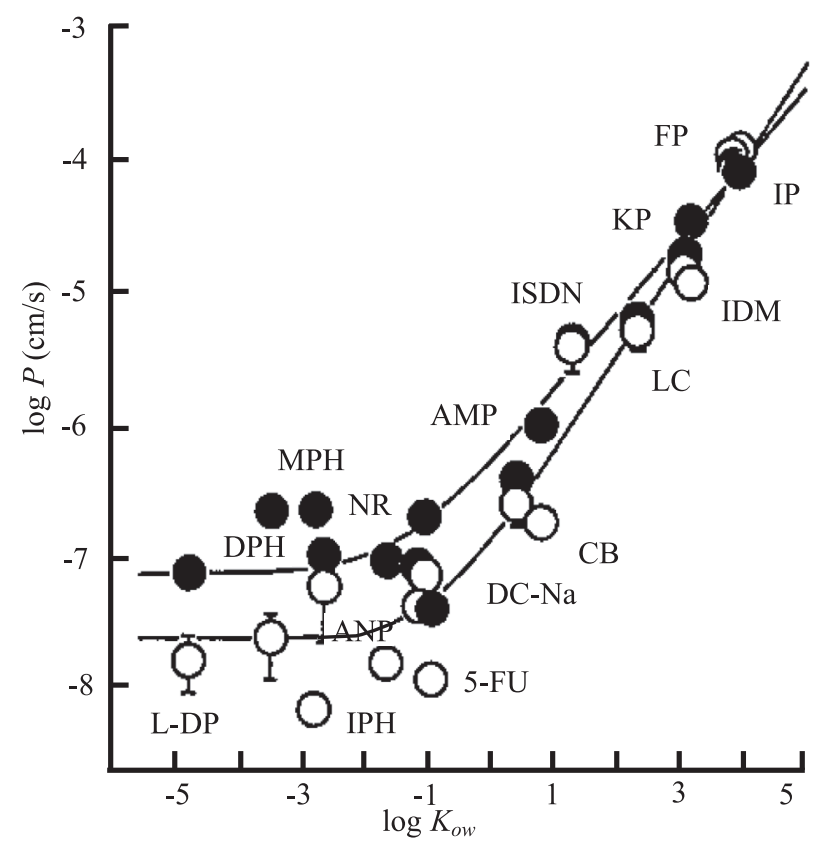

Fig. 4 Two layered skin modelにおける化学物質の典型的 な concentration-distance profile

$$
\log P=-6.3+0.71 \cdot \log K_{o w}-0.0061 \cdot M W
$$

ここで， $M W は$ 分子量（ダルトン）である。ただし， 残念なことに式 15 は分子量が 500 ダルトンを超えると 予測性が著しく低下する。

一方, Bos と Meinardi からの興味ある報告に「分子 量 500 ダルトン限界説 (500 Dalton rule)」がある ${ }^{11) 。 ~}$ 彼らは，(1)現在までに皮膚感作性を示す物質の分子量の ほとんどが500 ダルトン以下であること，また，(2)外用 剤やTDDS 中に含まれる薬物はほとんどが分子量 500 ダルトン以下であること, を基準としてこの経験説を提 唱している。

一方で，高分子やナノ材料が皮膚に浸透したと述べる 報告も数多く見られる。ナノ化して物質の活量が高くな ることがあるので，これらのすべてが間違っているとは いえないが, 500 ダルトン限界説を考慮に入れると，高 分子やナノ材料が簡単に経皮吸収すると述べた論文の多 くに疑問が残る。なお, 我々は最近, 直径 $500 \mathrm{~nm}$ の Fluoresbrite (Polyscience, Inc.) が毛囊中深さ 80-100 $\mu \mathrm{m}$ までは見られたことから，高分子の皮膚侵入経路として 経付属器官ルートの重要性を示唆した ${ }^{12)}$ 。

\section{4 皮膚適用した化学物質の皮膚中濃度}

経皮吸収性の評価は大変重要であるが, 皮膚局所での 効果を期待する外用剂では，これらより皮膚中濃度のほ うが重要であることが多い。

\section{$4 \cdot 1$ 定常状態皮膚（角層）中濃度}

定常状態を迎えたときの皮膚 (角層) 中濃度 $C_{s s}$ は式 4 の $t$ にを代入することにより求められ, 次式で示さ れる。

$$
C_{s s}=K C_{v}\left(1-\frac{x}{L}\right)
$$

式 16 およびFig. 3aから明らかなように, 皮膚（角層） 中濃度は皮膚表面から深くなるにしたがって低くなる。

また，皮膚（角層）中平均濃度 $\bar{C}$ は式 4 を $x$ に関し て皮膚（角層）表面 $x=0$ から $x=L$ まで積分し，さら に皮膚 (角層) 厚 $L$ で除して, 次式で表すことができる。

$$
\left.\bar{C}=\frac{K C_{v}}{2}\left\{1-\frac{8}{\pi^{2}} \sum_{m=1}^{\infty}\right\} \frac{1}{(2 m-1)^{2}} \exp \left(-\frac{D(2 m-1)^{2} \pi^{2}}{L^{2}} t\right)\right\}
$$

式 17 も同様に定常状態を迎えると, 次式で表すこと ができる。

$$
\bar{C}_{s s}=\frac{K C_{v}}{2}
$$

式 18 から明らかなように, 定常状態での皮膚（角層） 中平均濃度は $D$ ではなく, $C_{v}$ と $K$ で決定される。 


\section{$4 \cdot 2$ 角層下の透過抵抗の寄与が高い場合の皮膚中濃 度 : 2 層膜モデルの利用 ${ }^{13)}$}

1 層膜モデルは取り扱いが極めて簡単で皮膚中濃度が 極めて簡潔な式で示すことができる。しかし, 皮膚は複 雑な拡散膜で, 透過性の評価はともかく皮膚中濃度の評 価では 1 層膜では不十分であることが多い。すなわち， 皮膚中濃度の評価では, ヒト皮膚や動物皮膚を透過性(拡 散性）の違いから角層と生きた表皮・真皮（viable epidermis and dermis）に分けることが推奨される。

Fig. 5 に 2 層膜モデルの定常状態時の concentrationdistance profile を示す（1 層膜モデルは Fig. 2a 参照）。 2 層膜拡散モデルにおいては, 全体の透過係数 $P_{t o t}$ は角 層の透過係数 $P_{s c}$ と生きた表皮・真皮 (ved) の透過係 数 $P_{\text {ved }}$ を用いて以下のように示される。

$\frac{1}{P_{\text {tot }}}=\frac{1}{P_{s c}}+\frac{1}{P_{v e d}}$

また，これら透過係数の逆数 $1 / P_{t o t}, 1 / P_{s c}, 1 / P_{v e d}$ は それぞれの層の透過抵抗 $R_{t o t}, R_{s c}, R_{v e d}$ となるので

$$
R_{\text {tot }}=R_{s c}+R_{v e d}
$$

となる。さらに, Fig. 5 の sc と ved 界面での point a, $\mathrm{b}$ において, $\mathrm{a}-\mathrm{b}$ と $\mathrm{b}$ の比は $R_{s c}$ と $R_{\text {ved }}$ の比で示され ることになる。すなわち point b での薬物濃度 $C_{b}$ は次 式で表すことが出来る。

$$
C_{b}=K_{s c} C_{v} \frac{R_{\text {ved }}}{R_{\text {tot }}}
$$

以上より，第 1 層目（角層中）の定常状態薬物濃度 $C_{1, s s}$ は

$$
C_{1, s s}=K_{s c} C_{v}-\frac{K_{s c} C_{v}}{L_{s c}}\left(1-\frac{R_{v e d}}{R_{t o t}}\right) x
$$

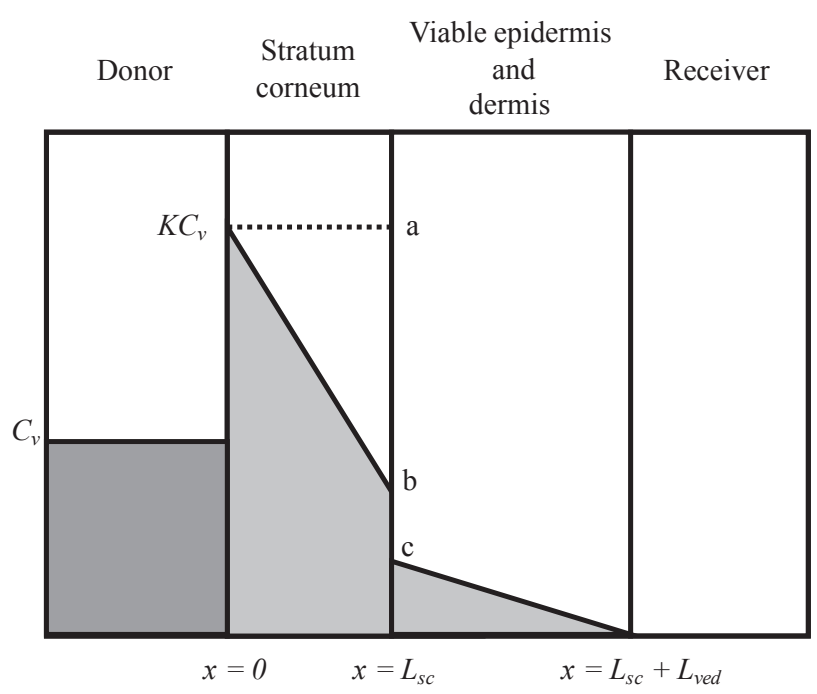

Fig. 52 層膜拡散モデルの定常状態時の concentration-distance profile
となる。ただし， $x$ は 0 から $L_{s c}$ である。

また, 第 2 層目（生きた表皮・真皮中）の薬物濃度 $C_{2, s s}$ は

$$
C_{2, s s}=K_{v e d} C_{v} \frac{R_{v e d}}{R_{\text {tot }}}\left(\frac{L_{s c}+L_{v e d}-x}{L_{v e d}}\right)
$$

となる。ただし， $x$ は $L_{s c}$ から $L_{s c}+L_{v e d}$ である ${ }^{14)} 。$ 式 22, 23 を変形することで (一部省略), 最終的に定常状 態時の皮膚中濃度 $\bar{C}_{s s}$ は次式となる。

$$
\bar{C}_{s s}=\frac{C_{v}}{2\left(L_{s c}+L_{v e d}\right)}\left\{K_{s c} L_{s c}\left(1+\frac{P_{t o t}}{P_{v e d}}+K_{v e d} L_{v e d} \frac{P_{t o t}}{P_{v e d}}\right\}\right.
$$

以上より，分配係数 $K$, 透過係数 $P$ を full-thickness skin と stripped skin 透過実験から求めれば, 2 層モデ ルで示される皮膚中各位置の濃度や平均皮膚中濃度を予 測することが可能となる。

\section{TDDS の実用化}

\section{$5 \cdot 1$ 実用化された TDDS}

TDDS が最初に（1980 年ごろ）実用化されたのはス コポラミンとニトログリセリンを含有したものである が，スコポラミン製剤は日本では実用化されなかった。 それ以降に日米欧を中心に多くの薬物を含有したTDDS が実用化された。Table 2 に我が国で実用化された主な TDDS を示す。

\section{$5 \cdot 2$ 経皮吸収促進剤の利用}

TDDS 開発の初期には吸収促進剂を含まないものも あったが，最近では吸収促進剤が含有されているものが 多い。エ夕ノールやミリスチン酸イソプロピルのような 脂肪酸エステルが実用化されている。代表的な吸収促進 剂を Table 3 にまとめて示す。吸収促進剤の種類によっ て様々な作用があるが，その大きなものの 1 つに角質細 胞間脂質の極性基への作用がある。すなわち, 吸収促進 剤が存在すると，角質細胞間に存在する隣り合う脂質同 士の相互作用が起こり, 脂質の充填構造に乱れが生じ る。脂質の充填構造の乱れは脂質 2 重層中の水の流れを 促進し，角層の水和が促進される。この現象により，と くに水溶性物質の角質細胞間拡散が促進される。

\section{$5 \cdot 3$ 外部エネルギーを用いた皮膚透過性の改善}

外部の物理エネルギーを利用した薬物の経皮吸収促進 法についても検討されている。一般に, 外部エネルギー を利用した方法は吸収促進剤を用いるより高い吸収促進 率が得られることが多く, 特に, 経皮吸収性が極めて低 いとされる水溶性薬物や高分子薬物の経皮吸収促進にも 有効である場合が多い。しかし，外部エネルギーを利用 した場合は，主薬を含有する半固形製剤や貼付剂に加え て，物理エネルギーを発生する外部機器が必要であるこ とが多く，「医療機器付き製剤」になってしまう。この 
Table 2 市販の経皮吸収型製剤（TTS, TDDS) *

\begin{tabular}{|c|c|c|}
\hline 分類 & 薬剤名（含量など） & 適用など \\
\hline 硝酸薬 & $\begin{array}{l}\text { 硝酸イソソルビド } \\
\text { ニトログリセリン }\end{array}$ & $\begin{array}{l}\text { 狭心症, 心筋梗塞 } \\
\text { 狭心症, 急性心不全 }(15 \sim 30 \mathrm{mg} / \text { 回, } 6 \text { 時間ごと) }\end{array}$ \\
\hline 女性ホルモン & エストラジオール & 更年期障害に伴う諸症状 \\
\hline 麻薬 & $\begin{array}{l}\text { フェンタニル }(2.5,5, \quad 7.5,10 \mathrm{mg}) \\
\text { ブプレノルフィン }(5, \quad 10,20 \mathrm{mg})\end{array}$ & 激しい疼痛や各種がん性疼痛の鎮痛 \\
\hline 禁煙補助剂 & ニコチン & 禁煙が必要な患者が医師の指導下に行う禁煙の補助 \\
\hline$\beta$ 刺激薬 & ツロブテロール & 気管支喘息, 急性·慢性気管支炎, 肺気腫 \\
\hline 抗コリン薬 & オキシブチニン & 尿失禁, 尿意切迫感, 頻尿治療薬 \\
\hline 認知症薬 & リバスチグミン (4.6, 9.5 mg) & アルツハイマー型認知症 \\
\hline ドパミン作動薬 & ロチゴチン & パーキンソン病 \\
\hline$\beta 1$ 遮断薬 & ビソプロロール (4.0, $8.0 \mathrm{mg})$ & 高血圧 \\
\hline
\end{tabular}

*本邦で市販されているもののみ示す。

Table 3 代表的な吸収促進剂

\begin{tabular}{|c|c|c|}
\hline グループ & 吸収促進剂 & 特 徵 \\
\hline 低級アルコール類 & エタノール, イソプロパノール & $\begin{array}{l}\text { 沉用性大, 炭素数が増える } \\
\text { と効果は少なくなる。 }\end{array}$ \\
\hline 多価アルコール類 & $\begin{array}{l}\text { プロピレングリコール， エチレングリコール， ブチレング } \\
\text { リコール，グリセリン，Transcutol }{ }^{\circledR}\end{array}$ & $\begin{array}{l}\text { 角層保湿性 } \\
\text { Transcutol }^{\circledR} \text { は吸収促進剤 } \\
\text { として開発された。 }\end{array}$ \\
\hline 脂肪酸 & オレイン酸, カプリン酸 & $\begin{array}{l}2 \text { 重結合のあるシス脂肪酸 } \\
\text { の効果が高い。 }\end{array}$ \\
\hline エステル類 & $\begin{array}{l}\text { 酢酸エチル，ミリスチン酸イソプロピル，アジピン酸ジエ } \\
\text { チル，モノオレイン酸グリセリン }\end{array}$ & 実用化されている \\
\hline$\alpha$ ヒドロキシ酸 & 乳酸, グリコール酸 & 角層のピーリング効果 \\
\hline 界面活性剂 & $\begin{array}{l}\text { ショ糖オレイン酸エステル， ショ糖ラウリン酸エステル， } \\
\text { ポリオシキエチレン -2-オレイルエーテル }\end{array}$ & $\begin{array}{l}\text { 低皮膚刺激性の非イオン界 } \\
\text { 面活性剂が有効 }\end{array}$ \\
\hline テルペン類, テルペノイド & $d$-リモネン, l-メントール, ハッカ油 & パップ剂などに配合 \\
\hline Azone とその類似物質 & Azone $^{\circledR}$, ピロチオデカン & \\
\hline 尿素とその誘導体 & 尿素, 1,3- ジフェニル尿素, 環状尿素誘導体 & $\begin{array}{l}\text { 角層保湿能 } \\
\text { 尿素は医薬品にも配合 }\end{array}$ \\
\hline サリチル酸類 & サリチル酸 & 角層溶解性 \\
\hline チオグリコール酸類 & チオグリコール酸カルシウム & ケラチン溶解性 \\
\hline ピロリドン類 & N-メチル -2-ピロリドン, ピロリドンカルボン酸 & 角層保湿性 \\
\hline スルホシキド類 & ジメチルスルホキシド, デシルメチルスルホキシド & 非プロトン溶媒 \\
\hline $\begin{array}{l}\text { アルキル -N,N-2 基置換アミノ } \\
\text { 酢酸類 }\end{array}$ & $\begin{array}{l}\text { dodecyl-N,N-dimethyl aminoacetate, dodecyl -2-methyl-2- } \\
\text { (N,N- dimethyl aminoacetate) }\end{array}$ & \\
\hline シクロデキストリン類 & $\beta$ - シクロデキストリン, ジメチル - $\beta$ - シクロデキストリン & 包接化合物を形成 \\
\hline
\end{tabular}

ことが物理的促進法の最大の問題点でもある。Table 4 に主な外部エネルギーを用いた経皮吸収促進法をまとめ て示す。

イオントフォレシス (iontophoresis) はその代表例で ある ${ }^{15)}$ 。この方法は，なんと一世紀以上も前に研究さ れていたが ${ }^{16)}$ ，数年前にスマトリプタンを含有したallin-one のイオントフォレシス貼付剂が米国で市販され た。エレクトロポレーション (electroporation, 電気穿 孔法）は，細胞への遺伝子導入に利用されていた方法を
薬物の経皮吸収促進に応用したものである ${ }^{17)}$ 。イオン フォレシスとエレクトロポレーションは同じ電気エネル ギーを使用するために電源や電極など共通するパーツが 多いが, それらの経皮吸収促進メカニズムは表に示した ように大きく異なる。そこで, 我々はこれら 2 つ物理 的経皮吸収促進法を併用して著しい経皮吸収促進効果を 得た ${ }^{18)}$ 。現在では, この 2 つの機能を有する美容機器 が実用化されている。

経皮吸収促進に対するマイクロニードルアレー（mi- 
Table 4 外部エネルギーを利用した薬物の皮膚透過促進

\begin{tabular}{|c|c|c|c|}
\hline 方法 & 原理 & 外部エネルギー & 備考 \\
\hline イオントフォレシス（IP） & $\begin{array}{l}\text { 電気反発 } \\
\text { 電気浸透圧 }\end{array}$ & 低電圧電気エネルギー & $\begin{array}{l}\text { Sumatriptan IP などがすで } \\
\text { に上市 }\end{array}$ \\
\hline エレクトロポレーション（EP） & 角層中への微細孔形成 & $\begin{array}{l}\text { 高電圧電気エネルギーの超短 } \\
\text { 時間照射 }\end{array}$ & $\begin{array}{l}\mathrm{IP} / \mathrm{EP} \text { 併用機器が美容皮膚 } \\
\text { 科領域で実用化 }\end{array}$ \\
\hline サーマルポレーション & 角層中への微細孔形成 & 熱エネルギー & \\
\hline ソノフォレシス (SP) & $\begin{array}{l}\text { キャビテーションやマイクロ } \\
\text { ストリーミングなど }\end{array}$ & 超音波エネルギー & 効果にバラツキ外部みられる \\
\hline マイクロニードルアレー & $\begin{array}{l}\text { マイクロニードルによる角層 } \\
\text { 中への微細孔形成 }\end{array}$ & & $\begin{array}{l}\text { 現在, もっとも活発に研究さ } \\
\text { れている }\end{array}$ \\
\hline 針なし注射器 & ジェット流の担体効果 & $\begin{array}{l}\text { バネ圧などによるジェット噴 } \\
\text { 射 }\end{array}$ & すでに実用されている \\
\hline マイクロ (ナノ) ポンプ & & ポンプ & \\
\hline
\end{tabular}

croneedle array）に関する研究は，ここ数年で大変活 発になってきているが, マイクロニードルについては詳 細を他に譲る。無針注射器はインスリンの自己注射用と して 1986 年に実用化された。注射針への恐怖心や，注 射針によって繰り返し皮膚を傷つけることを回避できる という利点がある。最も多いのは, バネの力を利用して, 液体を水圧で送達するもの（liquid injector）であるが, 特に粉末状のワクチンや遺伝子を送達するために, 高圧 ヘリウムガスで皮膚に送達する無針注射器（powder injector）も開発されている。無針注射器を貼付剤型に薄 く製造すれば，貼る注射剤になる。我々は，無針注射器 で処理した皮膚の小孔上に薬液を皮膚適用して薬物の皮 膚透過性を著しく上げることに成功した ${ }^{19,20) 。 ~}$

\section{TDDS の今後}

TDDSの欠点には，吸収速度が遅くばらつくこと， 高分子量薬の投与が困難なことなどが挙げられる。前述 したように，現在の研究は吸収促進剤から外部エネル ギーを用いた医療機器付きTDDS の研究に変わった。 投与部位としての皮膚は消化管や肺といった部位と異な り体の表面に位置しているところから，TDDSは微小 機器を併用した製剂とすることが容易である。

TDDS に利用できる製剤素材の研究も並行して進め られている。我々は最近非ラメラ液晶（NLLC）を形成 する脂質に注目している ${ }^{21,22)}$ 。これらはNLLC dispersion in water や NLLC powder として存在させることも 可能で, 皮膚上や皮内にも適用しうる剤形になる。 NLLCはリポソームなどに比べ親水性および親油性薬物 を高濃度に封入することができ，薬物放出性のコント ロールも可能である。現在, NLLCを含有する TDDS (テープ剂）も試作している。

またここれらの新しい製剤素材はInternet of things
（IoT）の考え方を用いて wifi 経由でインターネットにつ なぐ製剤にすることができる。患者の臨床検査值を同時 に得ることができれば，臨床検査值に応じた薬の投与ス ケジュールも設定できよう。さらに, Artificial intelligence（AI）やBio-MEMS 技術などを応用していくこ とで，いずれは体にインストールできる installable DDS（iDDS）という新しいタイプの TDDSに変貌させ ることが可能であると考えている。薬は投薬（dosage） するからインストール (install) する時代に，また，治 療（treatment）は修理（repair）に代わる時代がすぐ そこまでやってきている。IoT, AIを付与したiDDSが ヒト (human) ではなく Transhuman ${ }^{23)}$ に適用される のもそう遠い未来ではなさそうである。

\section{文 献}

1) D. Basketter, C. Pease, G. Kasting, I. Kimber, S. Casati, M. Cronin, W. Diembeck, F. Gerberick, J. Hadgraft, T. Hartung, J. P. Marty, E. Nikolaidis, G. Patlewicz, D. Roberts, E. Roggen, C. Rovida, J. van de Sandt, Skin sensitisation and epidermal disposition: the relevance of epidermal disposition for sensitisation hazard identification and risk assessment. The report and recommendations of ECVAM workshop 59. ATLA, 35, 137154 (2007).

2) S. Yoshino, T. Mitoma, K. Tsuruta, H. Todo, K. Sugibayashi, Effect of emulsification on the skin permeation and UV protection of catechin. Pharm. Develop. Tech., 19, 395-400 (2014).

3) H. Todo, E. Kimura, H. Yasuno, Y. Tokudome, F. Hashimoto, Y. Ikarashi, K. Sugibayashi, Permeation pathway of macromolecules and nanospheres through skin. Biol. Pharm. Bull., 33, 1394-1399 (2010).

4) H. F. Frasch, A random walk model of skin permeation. Risk Anal., 22, 265-276 (2002).

5) J. Crank, The Mathematic of Diffusion. $2^{\text {nd }}$ ed., Oxford University Press (1975). 
6) T. Hatanaka, M. Inuma, K. Sugibayashi, Y. Morimoto, Prediction of skin permeability of drugs. I. Comparison with artificial membrane. Chem. Pharm. Bull., 38, 3452-3459 (1990).

7) T. Hatanaka, M. Inuma, K. Sugibayashi, Y. Morimoto, Prediction of skin permeability of drugs. II. Development of composite membrane as a skin alternative. Int. J. Pharm., 79, 21-28 (1992).

8) Y. Morimoto, T. Hatanaka, K. Sugibayashi, H. Omiya, Prediction of skin permeability of drugs: comparison of human and hairless rat skin. J. Pharm. Pharmacol., 44, 634-639 (1992).

9) A. Leo, C. Hansch, Linear free-energy relationships between portioning solvent systems. J. Org. Chem., 36, 1539-5344 (1971).

10) R. O. Potts, R. H. Guy, Predicting skin permeability. Pharm. Res., 9, 663-669 (1992).

11) J. D. Bos, M. M. Meinardi, The 500 Dalton rule for the skin penetration of chemical compounds and drugs. Exp. Dermatol., 9, 165-169 (2000).

12) H. Todo, E. Kimura, H. Yasuno, Y. Tokudome, F. Hashimoto, Y. Ikarashi, K. Sugibayashi, Permeation pathway of macromolecules and nanospheres through skin. Biol. Pharm. Bull., 33, 1394-1399 (2010).

13) K. Sugibayashi, H. Todo, T. Oshizaka, Y. Owada, Mathematical model to predict skin concentration of drugs: Toward utilization of silicone membrane to predict skin concentration of drugs as an animal testing alternative. Pharm. Res., 27, 134-142 (2010).

14) T. Oshizaka, K. Kikuchi, W. R. Kadhum, H. Todo, T. Hatanaka, K. Wierzba, K. Sugibayashi, Estimation of skin concentrations of topically applied lidocaine at each depth profile. Int. J. Pharm., 475, 292-297 (2014).
15）杉林堅次, ファルマシア，37，385-388（2001）.

16) S. Leduc, Introduction des substances médicamenteuses dans la profondeur des tissus par le courant électrique. Ann. d'électrobiol., 3, 545-560 (1900).

17) M. R. Prausnitz, V. G. Bose, R. Langer, J. C. Weaver, Electroporation of mammalian skin: a mechanism to enhance transdermal drug delivery. Proc. Natl. Acad. Sci. U.S.A., 90, 10504-10508 (1993).

18) S. Tokumoto, K. Mori, N. Higo, K. Sugibayashi, Effect of electroporation on the electroosmosis across hairless mouse skin in vitro. J. Control. Release, 105, 296304 (2004).

19) N. Inoue, D. Kobayashi, M. Kimura, M. Toyama, I. Sugawara, S. Itoyama, M. Ogihara, K. Sugibayashi, Y. Morimoto, Fundamental investigation of a novel drug delivery system-A transdermal delivery system with jet injection. Int. J. Pharm., 137, 75-84 (1996).

20) N. Inoue, H. Todo, D. Iidaka, Y. Tokudome, F. Hashimoto, T. Kishino, K. Sugibayashi, Possibility and effectiveness of drug delivery to skin by needle-free injector. Int. J. Pharm., 391, 65-72 (2010).

21) K. Yamada, H. Todo, J. Yamashita, K. Miyamoto, S. Hashimoto, Y. Tokudome, F. Hashimoto, K. Sugibayashi, Preparation and evaluation of liquid-crystal formulations with skin-permeation-enhancing abilities for entrapped drugs. J. Oleo Sci., 60, 31-40 (2011).

22) W. R. Kadhum, N. Machida, H. Todo, K. Sugibayashi, Development and optimization of orally and topically applied liquid crystal drug formulations. J. Oleo Sci., 66, 443-454 (2017).

23) J. Carvalko, The Techno-human Shell-A Jump in the Evolutionary Gap. Sunbury Press (2012). 